\title{
A trombeta e os jogos
}

Fábio Vergara Cerqueira*

CERQUEIRA, F.V. A trombeta e os jogos. R. Museu Arq. Etn., 29: 75-91, 2017.

Resumo: $\mathrm{O}$ acompanhamento musical das práticas esportivas é uma característica marcante dos jogos na Grécia antiga, seja nos treinamentos, seja nas competições. Este acompanhamento se dava com instrumentos de sopro, especificamente o aulos e a salpinx (trombeta). Amplamente representado na pintura dos vasos áticos de figuras negras e de figuras vermelhas (séc. VI-V a.C.), o acompanhamento das práticas atléticas com o aulos, sobretudo nas provas que integram o pentatlo, tem recebido maior atenção dos estudiosos. Nosso objetivo é abordar a presença da trombeta nos jogos, representada com menos frequência no registro iconográfico, porém informada pelas fontes literárias de diferentes períodos, sobretudo do período imperial (nomeadamente, Plutarco, Ateneu e Pólux). Analisaremos as seguintes situações: acompanhamento musical de corridas (a pé ou de quadriga), contribuindo para marcar o ritmo; celebrações de entrega de prêmios; função comunicativa, pela divulgação de anúncios por intermédio da emissão de sinais; competições para trombeteiros, relacionadas à constituição de um perfil social deste músico-atleta baseado na força muito acima da média. Esta força superlativa, misturada com costumes bizarros, faz do trombeteiro um tipo popular no mundo helenístico-romano.

Palavras-chave: Jogos; Antiguidade Clássica; Música; Salpinx; Iconografia.

anções acompanhavam os exercícios, estas ajudavam a regrar os movimentos. ${ }^{1}$ Assim, os instrumentos musicais, em particular os de sopro, faziam parte da vida atlética. Conforme a região, a época ou a função, alternavam-se o aulos e a salpinx (trombeta) no apoio a atividades

*Professor Titular do Departamento de História da Universidade Federal de Pelotas. Doutor em Arqueologia Clássica. Bolsista Produtividade CNPq 1d 2019-2023 (Arqueologia da música na Magna Grécia). Pesquisador Fundação Humboldt. Pesquisa apoiada por CNPq, CAPES e Fundação Humboldt. <fabiovergara@uol.com.br>

1 Ateneu (XIV 629c): "by means of music and the care of their bodies they acquired courage, and to master movements under arms they exercised to the accompaniment of songs" (Burton Gullick). físicas. Na maioria das provas atléticas, confiavase ao aulos a incumbência de manter o ritmo correto dos movimentos. Nas corridas, porém, e em outras ocasiões, o instrumento escolhido era muitas vezes a trombeta.

O uso do aulos no acompanhamento de práticas desportivas, e suas respectivas funcionalidades, tema que dispõe de farto registro iconográfico na pintura dos vasos áticos dos séculos VI e V a.C., já despertou a atenção de muitos estudos, que, entre outros fatores, ressaltam a racionalidade inerente ao papel do instrumento como regrador dos movimentos nos treinamentos e provas atléticas, em especial no salto com halteres, considerada a prova de maior dificuldade entre as cinco que eram disputadas no pentatlo (arremesso de disco, arremesso de 
dardo, salto com halteres, corrida a pé, pugilismo) (Philostr. Gym. LV 4. Vergara Cerqueira 2005; 2016). No entanto, considerando a alternância entre o aulos e a salpinx na função de acompanhar provas atléticas nos agones, parece-nos relevante dedicar maior atenção a esta última.

De forma sucinta, "a salpinx consistia em um tubo bastante longo e reto, com orifício estreito e cilíndrico, finalizando com um sino proeminente em forma de tulipa na extremidade. Era usualmente de bronze com uma embocadura de osso, de acordo com Pólux. Os pintores de vaso sugerem o comprimento de 80 a 120 cm" (West 1992: 118). Trumpet (inglês) ou trompette (francês) exemplificam a tradução moderna mais usual, apesar de haver uma grande discussão sobre o sistema de embocadura do instrumento, havendo dúvidas se eram usadas ou não palhetas, aos moldes do moderno trompete. Gullög Nordquist (2014: 241) coloca que não há prejuízo em manter esta tradução, ao discutir esta problemática, a qual foi bem desenvolvida por Annie Bélis (1986: 212-217). Dada a dimensão e volume sonoro do instrumento, Roosevelt Rocha (2010: 147) prefere descrevê-lo como "um tipo de trompa de origem etrusca". Em razão da forma e dimensão do instrumento, considero mais adequada para o português a tradução "trombeta", descartando "trompa" ou "trompete", que sugerem outros tipos de aerófonos, que não possuem tubos exclusivamente retos.

Cabe uma observação quanto às fontes, uma vez que se verifica um descompasso entre o testemunho iconográfico e literário, que se dá de forma invertida entre o aulos e a salpinx, com relação à participação destes quer em práticas atléticas quer em práticas militares.

No caso da salpinx, ocorre o inverso do que com o aulos. Há um número reduzido de evidências iconográficas na cerâmica ática sobre o uso da trombeta no acompanhamento de jogos atléticos, ao passo que a documentação literária, mesmo que extemporânea, fornece testemunhos suficientes neste sentido. Uma questão que se coloca é definir se essa escassez de documentação imagética no contexto ático significaria a ausência do hábito de empregar a salpinx nas competições desportivas atenienses. Para buscar esta resposta, ajuda apoiar o raciocínio no caso do aulos. Se considerarmos as fontes literárias do período arcaico e clássico, não há testemunhos diretos sobre o costume do acompanhamento das provas e treinamentos atléticos com este instrumento. ${ }^{2}$ No entanto, o registro iconográfico mostra com fartura exemplos do aulos, acompanhando principalmente as provas que compõem o pentatlo. Desta forma, com base no testemunho da pintura dos vasos áticos, concluímos que a falta de testemunhos literários não significa a ausência do costume (do mesmo modo como a falta de testemunho imagético não implicaria a ausência do costume). É necessário raciocinar cotejando os dois testemunhos (literário e imagético). No caso da salpinx acompanhando práticas esportivas, não há de fato uma ausência total de registros, mas uma escassez, em comparação à abundância de exemplos iconográficos para o aulos. Aplicando à análise da trombeta a mesma linha de raciocínio aplicada à análise do aulos, deduzimos que esta escassez de testemunho (no caso, de testemunho iconográfico) não impõe concluir que houvesse uma escassez do hábito em questão. Assim, mesmo que poucos, os testemunhos iconográficos são relevantes. E a interface com as fontes literárias é estratégica para a interpretação, pois estas nos permitem diferenciar a lógica cultural subjacente ao uso de ambos os instrumentos e perceber, assim, a especificidade da demanda pela salpinx.

Neste estudo, analisaremos a presença da trombeta nos jogos quanto aos seguintes aspectos: acompanhamento musical de corridas (a pé ou de quadriga), contribuindo para marcar o ritmo; celebrações de entrega de prêmios; função comunicativa, na divulgação de anúncios por intermédio da emissão de sinais;

2 único testemunho que se tem é indireto. Trata-se do relato de Xenofonte (Hell. IV 8, 18) sobre um atleta de nome Tíbron, que, em uma manhã do ano de 391 a.C., saiu para treinar o arremesso de disco, acompanhado de um auletes, de nome Tersander, o qual, além de ser mencionado como um excelente músico, era forte e praticava a luta. Temos aqui a associação entre um treino atlético e a companhia de um auletes, sem informar, porém, com qual finalidade este músico, que também é atleta, o acompanha. 
competições para trombeteiros, relacionadas à constituição de um perfil social deste músicoatleta baseado na força muito acima da média, que faz dele um tipo popular no mundo helenístico-romano.

\section{A trombeta e as corridas (a pé e de quadriga)}

No que se refere ao atletismo, o primeiro aspecto que chama a atenção é a utilização da salpinx no acompanhamento de corridas. Sobre uma cratera ática de figuras vermelhas, datada do terceiro quarto do século V a.C., encontrada em Larissa, na Tessália (Fig. 1 = cat. 1 ), apesar do estado fragmentário identifica-se, no friso inferior, um homem que sopra a salpinx, ritmando os passos céleres dos atletas que se rivalizam em uma modalidade de corrida conhecida como hoplitodromia ("corrida em armas" ou, literalmente, "corrida de soldados").

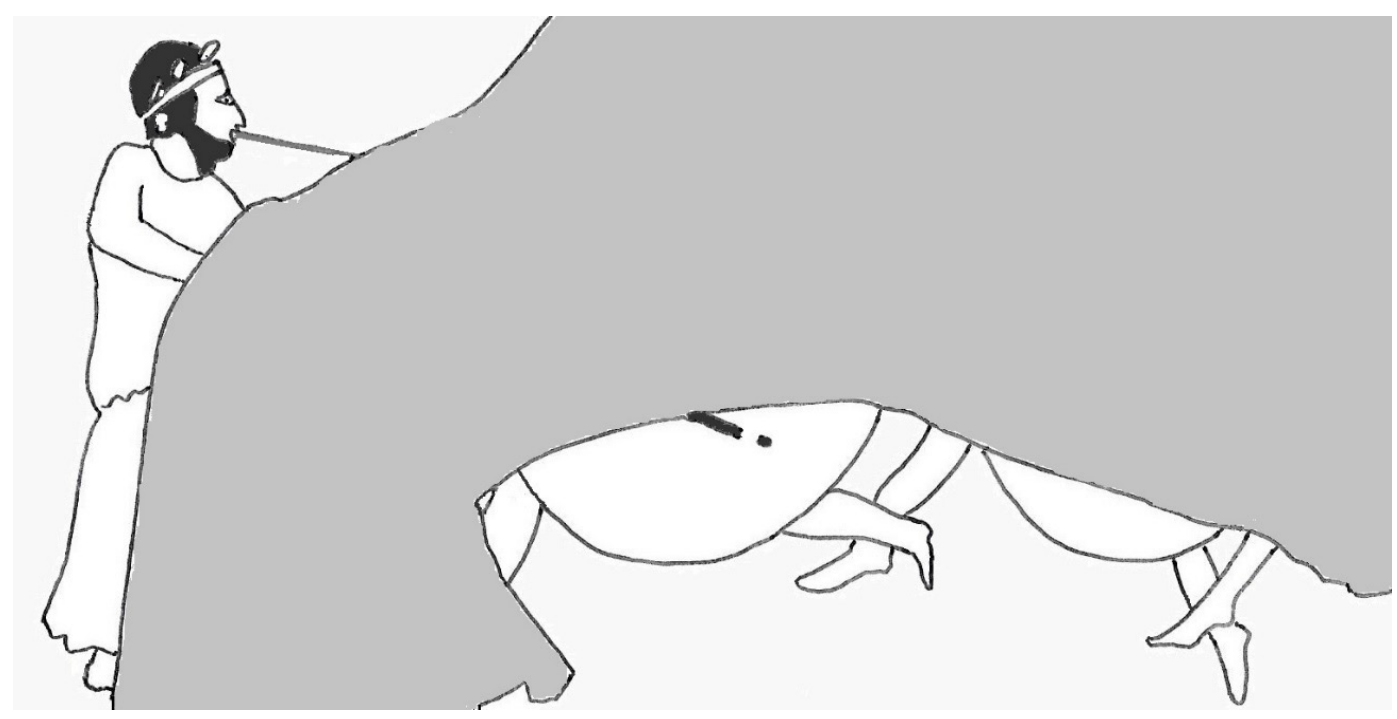

Fig. 1. Corrida de Soldados (corrida em armas), com trombeteiro. Cratera em cálice ática, figuras negras (fragmento). 440-430 a.C. Larissa, Museu Arqueológico, 86/101. Desenho: Fábio Vergara Cerqueira (2018).

Trata-se sem dúvida de um vaso muito especial, visto que ainda na Antiguidade o mesmo quebrou e foi restaurado, o que indica que se trataria de um bem bastante valorizado pelo proprietário. Seguindo um programa iconográfico bem definido, é possível que tenha sido feito sob encomenda (Tiverios 2008). As quatro cenas representadas apresentam competições bem conhecidas do Festival Panatenaico: duas provas musicais, a aulódia (canto acompanhado do aulos) e a aulética (apresentação instrumental de aulos solo), e duas modalidades de corrida a pé, a corrida de meninos e a corrida em armas. Da cena de corrida em armas, identificam-se: três corredores, dos quais estão preservadas apenas partes das pernas e os pés, de modo a evidenciar que correm aceleradamente; dois de seus escudos (em um deles, veem-se traços do emblema, que representaria talvez um corredor); e o trombeteiro, usando túnica acinturada e coroa de folhas. As inscrições, segundo Michalis Tiverios (2008), registram nomes conhecidos da Atenas de Péricles, salvo um desconhecido Amphikles e o próprio tocador de salpinx, identificado como Sigalos, que seria, conforme o autor, uma espécie de apelido. $O$ pintor da cratera de Larissa, de qualquer modo, ao fazer referência a personagens reais, tira do anonimato este trombeteiro que atuava profissionalmente nos jogos. 
$\mathrm{Na}$ "corrida em armas", introduzida em Olímpia em torno de 520 a.C., o atleta, levando consigo elmo, grevas e escudo, devia competir correndo dois estádios (c. 370 m). Logo a seguir, a prova foi adotada em outros jogos, como em Atenas, Nemeia, Corinto (Jogos Ístmicos), Elêusis (Festas Demétrias) e Plateia, na Beócia. Perto de Plateia, onde se deu a derradeira vitória sobre os persas em 479 , com a derrota do general Mardônios, ocorreram, promovidos pelas cidades-Estado gregas vencedoras, os Jogos da Liberdade, nos quais a hoplitodromia, cuja partida se dava no Monumento à Vitória, se destacava entre as demais provas, seguindo inclusive regras especiais: por exemplo, o desafio aumentava para quinze estádios (c. $2.800 \mathrm{~m}$ ) (Sweet 1987: 149)3.

A hoplitodromia possuía, na sua origem, uma finalidade bélica (Philostr. Gym. VII), voltada ao treinamento físico de guerreiros fortemente armados que precisariam, ao mesmo tempo, correr com agilidade no campo de batalha, proeza militar que teria determinado a vitória dos gregos em Maratona em 490 a.C. Atletas com muita experiência na corrida em armas eram considerados "hábeis no manejo das armas pesadas" (Philostr. Gym. XLIII) .

Vale lembrar que esta prova teria atingido muita popularidade entre os atenienses, talvez inclusive associada a um sentimento ufanista

3 Filostrato (Gym. VIII) apresenta alguns aspectos relacionados à hoplitodromia do festival de Plateia: «On regardait comme les meilleurs athlètes en armes les gens de Platée en Béotie; et cela pour les raisons suivantes: la longueur de la course [qu'ils avaient à faire]; leur armure, qui descendait jusqu'aux pieds et les couvrait comme s'ils étaient au milieu d'un combat réel; l'institution de ce concours fondée sur un fait d'armes brillant: la guerre médique; la coutume où les Grecs étaient de célébrer ces jeux en vue des barbares; enfin, la loi promulguée à l'égard de ceux qui voulaient prendre part au concours, tel qu'il est établi à Platée; dans cette ville, en effet, celui qui avait déjà reçu la couronne une première fois devait, s'il voulait prendre part à un nouveau concours, donner des otages pour son corps, car il était condamné à mort s'il était vaincu» (Ch. Daremberg).

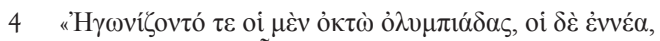

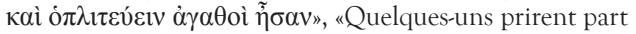
aux concours pendant huit olympiades, d'autres pendant neuf, et ils étaient habiles dans le maniement des armes pesantes» (Ch. Daremberg). subsequente às Guerras Pérsicas, por aludir a uma pretensa superioridade da infantaria grega sobre os arqueiros persas. Exemplo disso é a estatueta ática de bronze de um atleta corredor de hoplitodromia conservada em Tübingen, originalmente armado com elmo e escudo, que teria sido depositada como ex-voto em um santuário, em torno de 485 a.C., por um vencedor nesta competição (Zimmer 2015) ${ }^{5}$. Sabemos de um corredor que teria vencido a hoplitodromia em vários jogos pan-helênicos, entre eles os Jogos da Liberdade, de Plateia, os Jogos Ístmicos, de Corinto, e as Grandes Eleusínias (Festas Demétrias) de Elêusis. Como reconhecimento por suas conquistas, os atenienses ter-lhe-iam concedido a cidadania e dedicado uma estátua e uma coroa de folhas (IAG 59 = Moretti 1953: n. 59. Sweet 1987: 149).

Por que razões o pintor ático da cratera de Larissa mostra o acompanhamento da prova com a trombeta e não com o aulos? Pelos ruídos produzidos pelos armamentos, que tornariam o som do aulos inaudivel? Ou seria em razão de uma associação simbólica? Considerando a temática bélica, evocada pela corrida de hoplitas, talvez se apresentasse mais coerente, aos olhos dos atenienses, o acompanhamento musical com a salpinx, que era usada com mais frequência para ritmar as falanges hoplíticas áticas (diferentemente das falanges espartanas, junto às quais prevalecia o aulos) (Thuc. V 70. Plb. IV 20, 6-7. Gell. I 11, 3. Vergara Cerqueira, 2016).

A pintura de outros vasos registra, porém, a possibilidade de corridas a pé serem acompanhadas pelo aulos. Esse deve ser o caso dos quatro atletas que correm observados por um gymnastes, representados em um kantharos de figuras negras da Biblioteca Nacional de Paris (cat. 2), em uma cena em que, no interior de uma palestra ou ginásio (como indicam as colunas demarcando o espaço), o acompanhamento do aulos está

5 “Der Tübinger Waffenläufer". Estatueta de bronze, H 16,35cm. Proveniência: Ática. Tübingen, Museum der Universität, inv. no KLA-Or-1. 490-485 a.C. Faltam-lhe o elmo e o escudo. Imagem disponível em: <https://www. emuseum.uni-tuebingen.de/objects/3665/waffenlaufersog-tuxsche-bronze?ctx=e084bb01-a52b-449b-bb4c6058770c48f9\&idx=407>. Acesso em: 8 jul. 2018. 
associado ao mesmo tempo ao arremesso de disco e à corrida. As cenas de palestra se repetem no entorno do kantharos, alternando a composição dos grupos, aludindo a diferentes modalidades esportivas que compõem o pentatlo (um gymnastes supervisiona um atleta que salta com halteres; dois pugilistas entre um atleta e um gymnastes; um gymnastes e quatro corredores; um gymnastes e um discóbolo; um gymnastes, voltado para a esquerda, olhando para trás, para a direita, onde se encontra um auletes soprando os tubos do aulos). Uma vez que os atletas são todos adultos e com barba, e dada a presença de vários treinadores, a cena, que certamente não mostra jovens em idade escolar praticando esporte, representa mais propriamente os treinamentos de atletas profissionais.

Em uma cratera com voluta proveniente da Acrópole de Atenas (Fig. 2 = cat. 3), vemos um auletes soprando o instrumento, disposto entre dois corredores nus que se preparam para a corrida. Diferentemente do kantharos de Paris, a cratera da Acrópole parece representar uma cena de competição, como sugere o traje mais pomposo do personagem à direita do corredor.

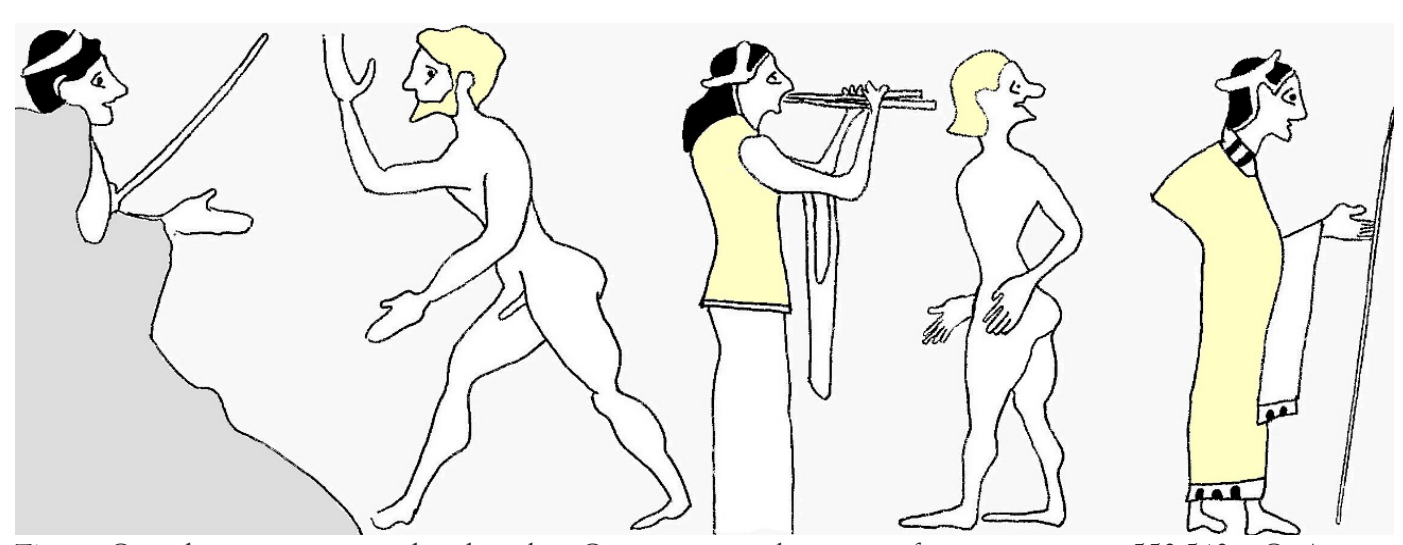

Fig. 2. Corrida a pé, com tocador de aulos. Cratera com voluta ática, figuras negras. c. 550-540 a.C. Atenas, Museu Arqueológico Nacional, Coleção da Acrópole, inv. no 654. Desenho: Fábio Vergara Cerqueira (2018).

No acompanhamento dessas corridas, é possível que o auletes tocasse a Endrome de Hiérax, melodia lembrada por Plutarco (de Mus. 262, 1140d), no início do séc. II d.C., como uma canção muito antiga, que teria sido composta para o acompanhamento de corridas ou do salto com halteres, como indica o seu nome (a partícula en + dromos, que significa corrida). Ateneu (570b) menciona uma canção de Hiérax, que devia ser a mesma que Pólux (IV 78; IV 79) denomina Hierakios ou melos Hierakion, tocada ao aulos nas Antesfórias, festival argivo em honra a Hera. O suposto compositor Hiérax seria o nome de um músico lendário, um auletes que, conforme Pólux (IV, 79), teria sido amante e aluno de Olimpos (Rocha 2010: 192-193, n.196-197).
Qual poderia ser o motivo pelo qual algumas corridas a pé eram acompanhadas pelo aulos, e outras, pela salpinx? A princípio, devemos raciocinar como músicos e considerar a acústica. Provas de velocidade, de curta distância e de explosão física, podiam ser realizadas no interior de um ginásio ou palestra, em local limitado por uma área construída, no interior da qual os sons do aulos poderiam ser ouvidos. Já a hoplitodromia, como aquela representada na cratera fragmentária de Larissa, era uma prova que combinava velocidade, agilidade e sobretudo resistência, realizada em estádios, ambiente mais aberto, em que a potência acústica do aulos seria insuficiente. Se considerarmos o estádio de Olímpia, o som do instrumento de sopro precisaria cobrir os 
dois lados da pista, de aproximadamente 180 m cada. Devemos lembrar ainda do barulho das armas e eventualmente do vento. Não parece acusticamente viável o uso do aulos nesta situação! Nas longas distâncias, o efeito esperado de seu som seria inoperante, sendo necessário um instrumento mais sonoro, como a salpinx.

A acústica seria a única razão? Penso que a ela se agregava o valor simbólico, tendo em vista a relação mais consolidada entre o som metálico da salpinx e o sentimento belicoso (Vergara Cerqueira 2018). Na "corrida de soldados", o jovem desportista era testado em uma capacidade militar muito especial para a infantaria: a capacidade de os hoplitas, levando armamento pesado (ao todo cerca de $23 \mathrm{~kg}$ ), fazerem um ataque rápido e surpreendente no início do combate, correndo agilmente na direção da arquearia inimiga, lembrando que os arqueiros se situariam a uma distância estimada de 350 a $400 \mathrm{~m}$, aproximadamente os dois estádios que deveriam ser corridos na hoplitodromia em
Olímpia. A bravura necessária a este atletasoldado encontraria nos toques brônzeos da trombeta o mesmo timbre que o encorajava à guerra (Gell. I 11, 1. Philostr. Gym. VII 18-19). ${ }^{6}$

Mas e o repertório? É muito improvável que a canção aulética tradicional, informada por autores tardios como Ateneu, Plutarco e Pólux, fosse empregada também na salpinx, instrumento com possibilidades melódicas mais limitadas. Possivelmente, em provas como a hoplitodromia, o repertório para a salpinx se inspiraria na música marcial, como as marchas e fanfarras.

No caso das corridas de quadriga, a salpinx não é mais uma opção, mas uma absoluta necessidade. Sobre a tampa de uma olpé de figuras negras conservada em Paris (Fig. 3 = cat. 4), vemos um músico soprando a salpinx enquanto três quadrigas disputam uma corrida. Observe-se que o tubo do instrumento é bastante longo, correspondendo a aproximadamente dois terços da estatura do músico (logo, entre 55 e $60 \mathrm{~cm}$ ), garantindo assim uma maior sonoridade.

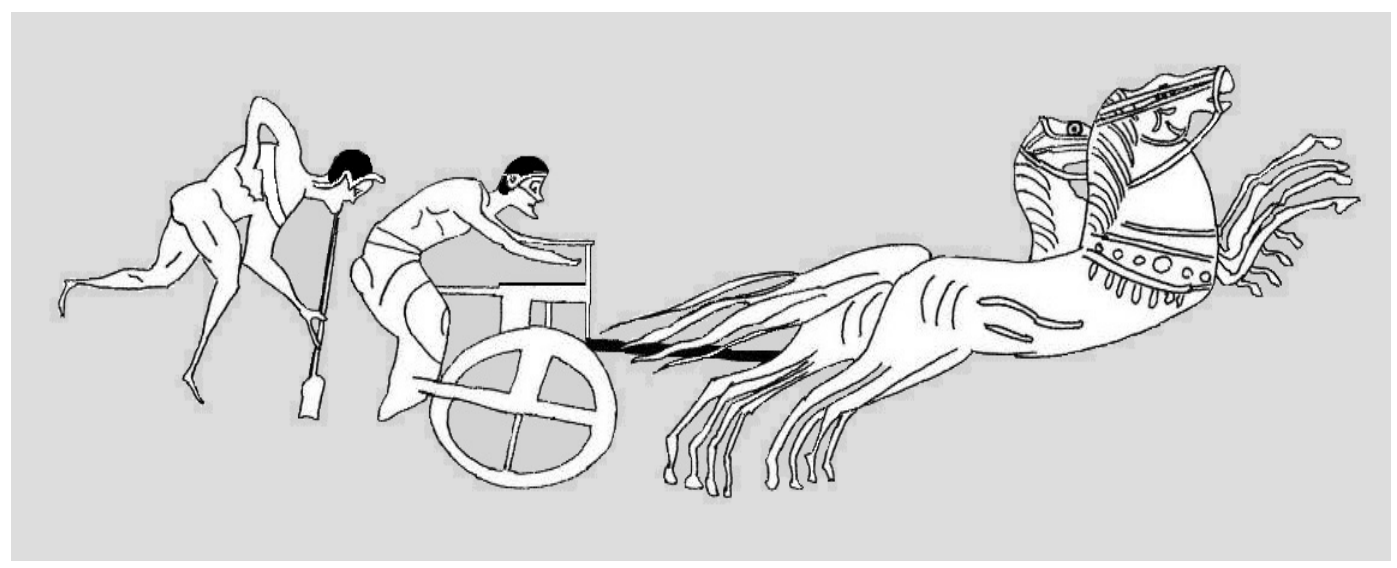

Fig. 3. Corrida de carros (quadrigas), com trombeteiro. Tampa de uma olpé ática, figuras negras. Paris, Cabinet des Médailles, 54 (182). Segunda metade do século VI a.C. Desenho: Fábio Vergara Cerqueira (2018).

O acompanhamento das corridas de quadrigas com a trombeta devia ser um hábito comum em Atenas, pois despertou inclusive o interesse de um poeta dramático que influenciou a kylix de Cambridge do Pintor de Nikósthenes (Fig. 4 = cat. 5). Sobre as duas faces do vaso, sátiros e mênades envolvem-se em ocupações humanas, evidenciando que o pintor buscou inspiração na cenografia de um drama satírico.

6 A salpinx servia para "incitar e inflamar os ânimos", ut excitarentur atque evibrarentur animi, quod cornua et litui moliuntur (Gell I.11.1), "provocando os jovens às

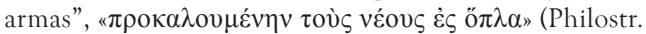
Gym. VII 18-19). 


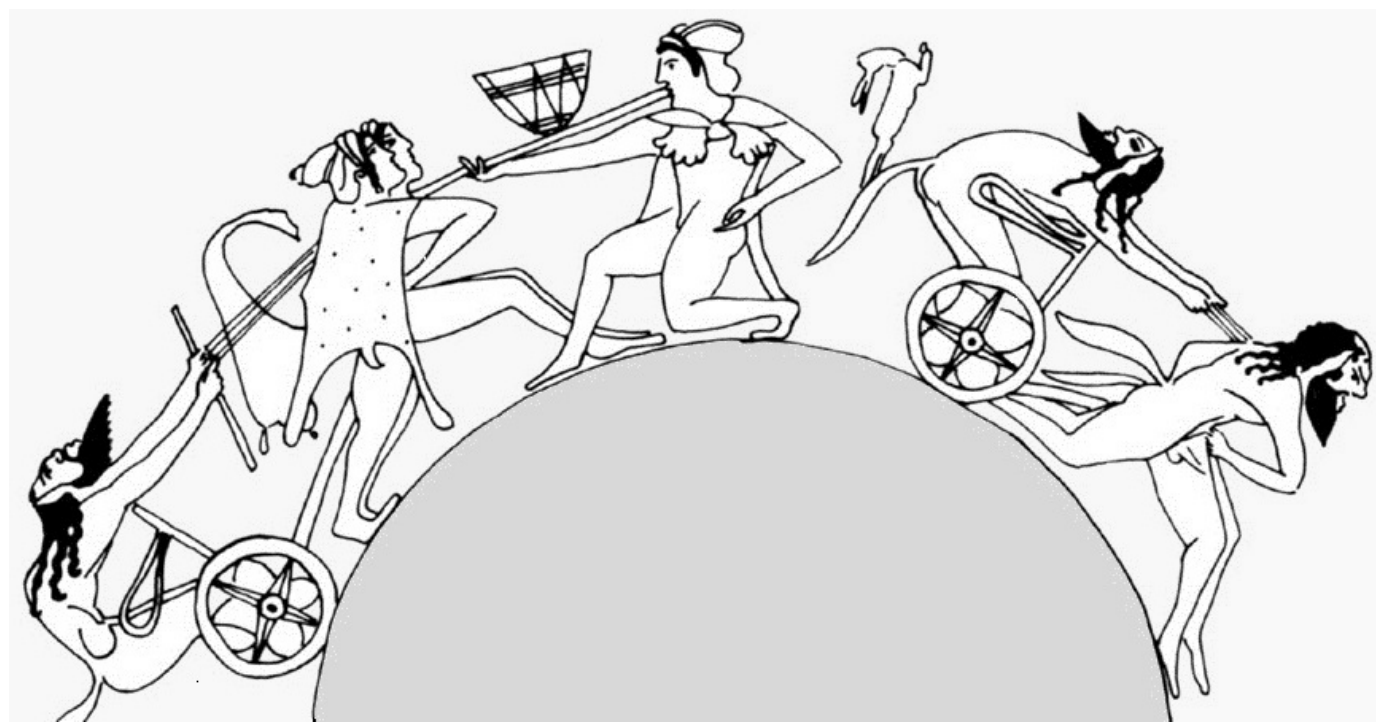

Fig. 4. Sátiros e mênades numa corrida de carros, com trombeteiro. Kylix ática, figuras vermelhas. 520-510 a.C. Cambridge, University, 37.17. Fonte: Lissarrague, 1987, fig. 57B (reelaborada).

Sobre a face A, divertem-se embriagados num komos, estando um dos sátiros tocando krotalon e os outros sentados sobre um odre ou sobre uma cratera. Sobre a face B, uma mênade vestindo uma pele de pantera toca trombeta, acompanhando dois carros, um deles conduzido por um sátiro e tracionado por duas mênades, outro conduzido por um sátiro e puxado por outros dois. A sonoridade da salpinx, no espaço acusticamente favorável do teatro, deve ter contribuído para um grande efeito da cena.

\section{Celebração de entrega dos prêmios: salpinx e aulos}

Algumas funções eram partilhadas entre os dois instrumentos, variando conforme a região, o período e o tipo de fonte. É o caso das premiações. ${ }^{7}$ Segundo Philostratos (de arte gymnastica libellus VII, 18), a salpinx anunciava a proclamação do vitorioso, antecedendo a concessão do prêmio. Nos Jogos Píticos, no entanto, conforme testemunho de Plutarco

7 Sobre as premiações, ver: Kefalídou, 1999. Especificamente sobre os instrumentos musicais nas premiações, ver: Kefalídou, 1996, p. 45. (de Mus. 135, 1136a), essa função era atribuída aos auletai. A análise da iconografia dos vasos áticos indica igualmente que em Atenas, nas cerimônias de premiação, poder-se-iam usar um ou outro.

Panos Valavanis (1990: 350) propõe a identificação de cinco registros na iconografia dos vasos áticos, referentes especificamente às Panateneias. Quatro destes registros são fragmentos de identificação ainda incerta, que o autor inclui no corpus de representações de premiações na panateneias, tendo em vista se tratarem de fragmentos de ânforas panatenaicas $^{8}$. Por outro lado, Valavanis inclui como exemplo de premiação com trombeta a ânfora panatenaica do arcontado de Teofrasto, conservada no Louvre (Fig. 5 = cat. 6), que consiste em um testemunho único e inequívoco, na pintura dos vasos áticos, da atuação da dupla arauto/trombeteiro na cerimônia de premiação.

8 1) Fragmento ático. Atenas, Museu Arqueológico do Cerâmico, inv. PA 156. Valavanis, 1990: fig. 20. Valavanis, p. 149. 2) Fragmento ático. Tebas, Santuário Kabirion, no PA 12. Braun \& Haevernick, 1981:90. Valavanis, p. 149. 3) Fragmento ático. Tebas, Santuário de Kabirion, n PA 36a. Braun \& Haevernick, 1981: 92. Valavanis, p. 149. 4) Kiel, Museu Arqueológico, B 455. Referência : CVA Kiel 1, nº 6, pr. 15. Valavanis, p. 149. 
Na cena de premiação, vemos, no lado esquerdo, dois atletas jovens e imberbes nus, e, no lado direito, dois adultos com barba, o primeiro com cajado e vestindo himation, o segundo, no canto direito, vestindo um chitoniskos (túnica curta) e clâmide (manto curto). As duas figuras de jovens, um parado, outro, no canto esquerdo, correndo, são representadas como atletas vencedores, ao segurarem um ramo de palmeira. Seria uma duplicação do mesmo atleta: mais ao centro, calmo, sendo proclamado vencedor, segurando um ramo de palmeira, levando uma tainia (fita) sobre o ombro e uma coroa de folhas na cabeça. O jovem do canto esquerdo, corre para a aclamação do público, levando o ramo de palmeira, com tainia na cabeça, iniciando a periagermos (volta triunfal na pista). Já os dois personagens adultos devem ser identificados como arauto e tocador de trombeta. $\mathrm{O}$ arauto está ao lado do atleta, apoiado sobre o cajado, com a cabeça levemente erguida e a boca aberta, para aclamar o nome do vencedor. Atrás dele (à direita), a figura do trombeteiro. Por já ter cumprido a sua tarefa de estabelecer o silêncio, para que o arauto possa anunciar o vencedor, ele se afasta da cena, levando sua salpinx na mão direita abaixada (Miller 2009: 112, fig. 37; Valavanis 1990: 345-346) .

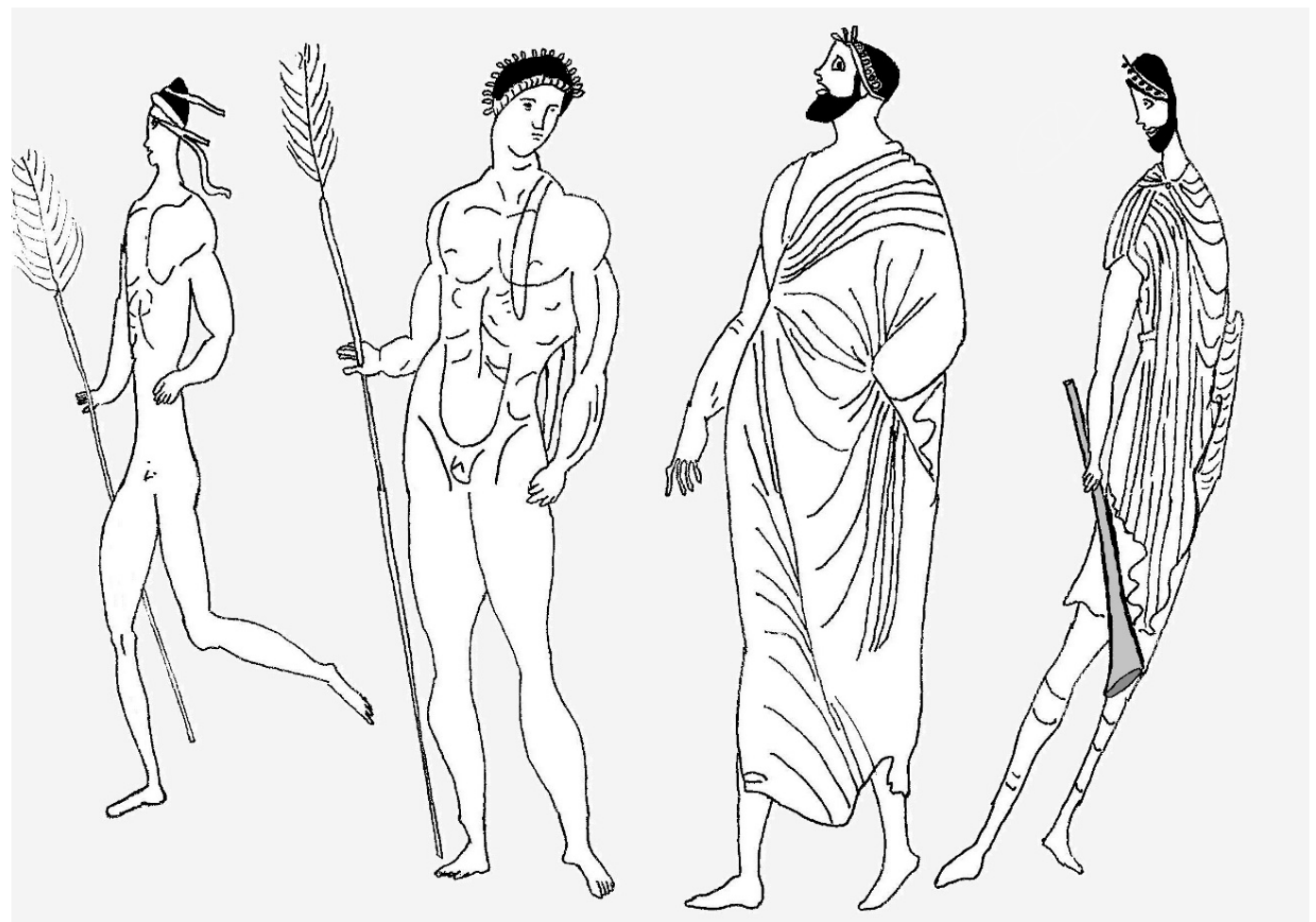

Fig. 5. Cerimônia de premiação (arauto anuncia vencedor), com presença de trombeteiro. Ânfora panatenaica. Arcontado de Teofrasto. Paris, Louvre, MN 706 (N 3163). 340-339 a.C. Desenho: Fábio Vergara Cerqueira (2018).

Ao mesmo tempo, a pintura de vasos áticos nos apresenta, em número relativamente maior, a performance do auletes nas cerimônias de entrega de prêmio aos vencedores, tal como nos informa Plutarco sobre Delfos. Assim, sobre a cobertura de uma kylix de figuras negras de Boston (cat. 7), vemos um atleta nu, adulto, em companhia de

9 Valavanis identifica o personagem que anuncia o vencedor como "árbitro", ao passo que, acertadamente, Miller o identifica como arauto. 
outros atletas, sendo coroado por um agonothétes. Sobre duas crateras campaniformes, uma de meados do séc. V, outra do final desse século, vemos um mesmo esquema iconográfico: uma Niké alada aproxima-se, trazendo na mão um stephanos (coroa) ou tainia (fita), para coroar um efebo nu, que devemos identificar como um niketes (vencedor). Num caso o atleta venceu a prova de arremesso de dardos (cat. 8), no outro, de disco (cat. 9); nos dois vasos, a coroação anunciada pela Niké é acompanhada pela música de um auletés, vestindo elegante chiton poderes ornado com bolinhas bordadas. A diferença é que na cratera de Ferrara (cat. 8) o músico é um jovem imberbe, ao passo que na cratera de Atenas (cat. 9) é um adulto com barba. Vemos, então, a possibilidade de atuarem na premiação, com trajes de músico profissional, tanto um adulto quanto um jovem, não se podendo fazer inferências sobre a conjuntura do agon representado, se um certame escolar ou uma competição realizada no contexto dos grandes festivais.

Uma kylix em Heidelberg atribuída ao Pintor de $\mathrm{C}($ Fig. $6=$ cat 10$)$ representa um importante momento da glória do atleta vencedor, quando é recepcionado em sua cidade com honras de herói. O jovem (?) traz sobre sua cabeça o prêmio, um trípode; os kerai trazidos por alguns dos personagens anunciam a festa que será realizada em sua homenagem. Um auletes o homenageia, executando talvez a melodia de uma ode epinícia, enquanto outros personagens ovacionam o niketes.

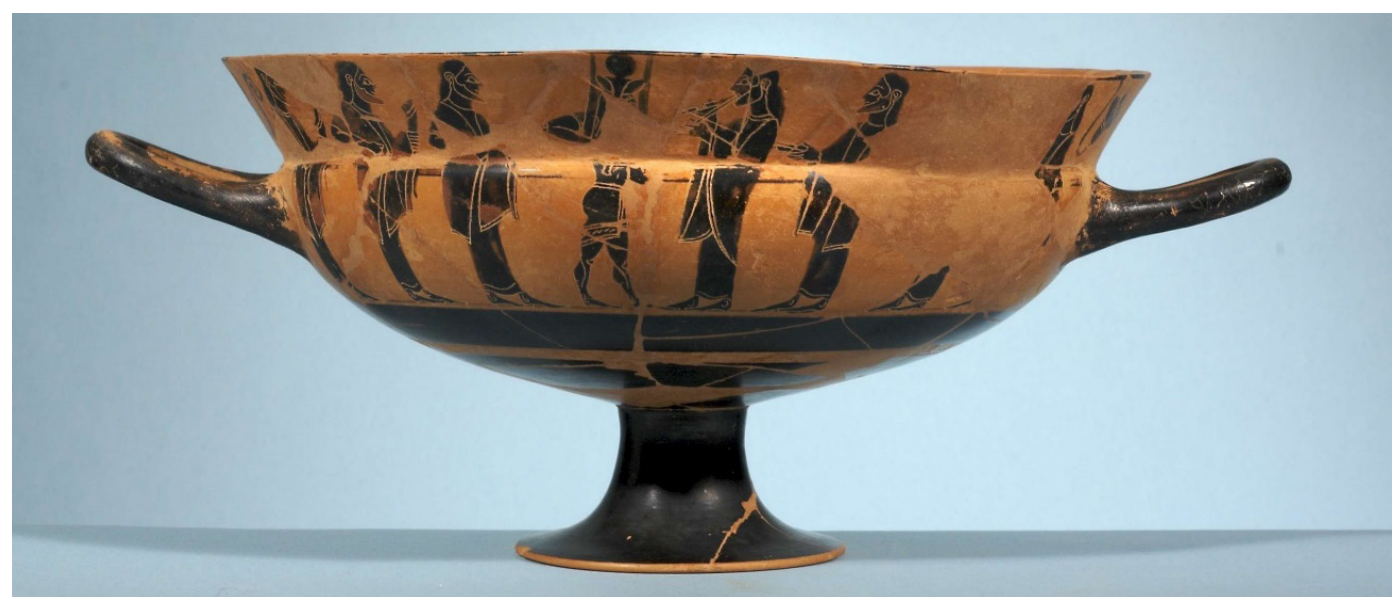

Fig. 6. Kylix ática, figuras negras, Pintor C (ABV 51/1; Add² 13), c. 575-550 a.C. Heidelberg, Antikesammlung der Universität Heidelberg, S 1. Fotografia: Hubert Vögele.

O aulos e a salpinx eram entre si excludentes na cerimônia de premiação? Não necessariamente, pois a trombeta tinha uma função específica, para a qual o aulos não teria competência acústica. Como define Pólux (IV 85), a função da salpinx era estabelecer o silêncio em meio à multidão barulhenta, pois, como aponta Sêneca (Ep. LXXVIII 16), somente assim se podia ouvir o nome do vencedor ${ }^{10}$. E esta foi

10 Nos quoque evincamus omnia, quorum praemium non corona nee palma est nee tubicen praedicationi nominis nostri silentium faciens, sed virtus et firmitas animi et pax a missão que o trombeteiro desempenhara, na situação representada na ânfora panatenaica do arcontado de Teofrasto (Valavanis 1990: 354), antes do momento em curso, no qual o arauto anuncia o vencedor.

in ceterum parta, si semel in aliquo certamine debellata fortuna est. "So let us also win the way to victory in all our struggles,-for the reward is not a garland or a palm or a trumpeter who calls for silence at the proclamation of our names, but rather virtue, steadfastness of soul, and a peace that is won for all time, if fortune has once been utterly vanquished in any combat" (R. Gummere) (grifo nosso). 
Função comunicativa nos festivais: fazer anúncios por meio dos toques da trombeta

Nigel B. Crowther (1994: 146-147) lista um conjunto de funções que o trombeteiro devia cumprir nos festivais atléticos. Ele atuava em parceria com o arauto, apoiando-o. Sua principal atribuição era avisar a multidão de que o arauto precisava fazer um anúncio. Seu papel central era essencialmente comunicativo. Em um contexto como os Jogos Olímpicos e os Jogos Píticos, marcados pela presença de uma multidão vinda de todos os cantos do mundo grego, com pessoas circulando entre os vários eventos e prédios do santuário, é presumível que houvesse muito barulho e, assim, dificuldade para se anunciar informações. A trombeta funcionava então como o melhor mecanismo para silenciar a multidão, para que o arauto pudesse comunicar sua mensagem (Poll. IV 87-8).

O testemunho de Pausânias informa inclusive onde o arauto e o trombeteiro se localizariam em Olímpia para cumprirem a função comunicativa de forma mais eficiente. Segundo ele, havia um altar no santuário próximo à entrada que levava ao estádio. Neste altar, os habitantes de Élis não faziam sacrifícios a nenhuma divindade, "mas era usual que os trombeteiros e os arautos ficassem aí durante os jogos" (Paus. V 22, 1). ${ }^{11}$ Tratava-se de uma localização privilegiada do ponto de vista acústico e visual, facilitando a audição das mensagens e a função de despertar o interesse do público, que poderia enxergar bem a dupla que transmitia os anúncios oficiais dos organizadores (Bowyer 2016: 194-195).

Paulatinamente, o salpiktes recebeu outras incumbências nos agones, entre elas: escoltar o agonothetes (juiz) (Him. Or. LXI 5); dar a partida da corrida de quadrigas nos Jogos Píticos (Soph. El. 711); anunciar a última volta na corrida de cavalos em Olímpia e em outras provas equestres (Paus.VI 13, 9). Pausânias,

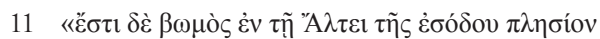

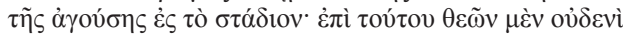

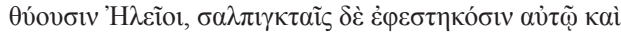

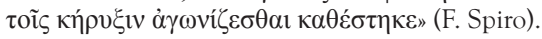

nesta passagem, relata-nos a curiosa história da égua Aura ("brisa"), que teria ocorrido em 512 a.C. Participando da competição em Olímpia, no começo da corrida de cavalos, ela jogou no chão o jóquei que a pilotava, o coríntio Fídolas, mas continuou a correr. Ao alcançar a curva final, ela ouve o toque da trombeta, e acelera o passo. Assim que cruza a linha de chegada onde se encontravam os árbitros, ela para, compreendendo que tinha vencido. Os juízes teriam aclamado Fídolas vencedor, e lhe permitiram dedicar uma estátua a sua égua. Difícil decidir entre a veracidade e a imaginação nesta história. De qualquer forma, imaginária ou real, ela indica que a presença da salpinx na corrida de cavalos seria considerada importante não somente para os jóqueis, mas também para os animais, que compreenderiam seus toques (Bowyer 2016: 195-196). Neste contexto, vale lembrar o testemunho de Xenofonte (Eq. III 11-12), que a meu ver confere credibilidade à história da égua Aura, pois, analogamente, a salpinx seria usada para disciplinar a sincronia dos comandos e manobras da cavalaria, mostrando a facilidade maior dos cavalos e cavaleiros em seguir as indicações do trombeteiro. Testemunhos referentes à sensibilidade e resposta dos cavalos aos toques da trombeta estão presentes inclusive na tragédia ateniense (Aesch. Th. XI 394-5. Soph. El. 711), indicando que a audiência veria esta situação como verossímil, como familiar a um hábito conhecido.

As narrativas mitológicas dão conta de outros usos comunicativos nos jogos, que deveriam remeter a práticas da vida cotidiana. Segundo Ovídio (Met. X 652), a trombeta dava a partida das carreiras a pé de Hippomenes e Atalanta, e, conforme Virgílio (Aen. V 139), fazia a abertura dos jogos fúnebres.

A salpinx era com frequência anunciada como instrumento da guerra e da paz - na guerra, guia as tropas, na paz, anuncia as vitórias dos campos de batalha, dos palcos e dos jogos, vitórias militares e agonísticas (Anth.Pal. IV 46, 151, 159, 195). Num epigrama votivo atribuído a Crinágoras de Mileto, da Coroa de Filipe, ativo no final da República e início do Império, homenageiam-se "as fanfarras altissonantes 
da trombeta tirreneana que com frequência ressoavam (...) para celebrar uma dupla vitória", mas que, dessa vez, diante das glórias trazidas por Demóstenes a Mileto, soavam "em honra de três coroas", e "jamais um pavilhão de bronze vibrou com um sopro tão possante" (Crinágoras de Mileto, "A Demóstenes", Anth.Pal. VI 350) ${ }^{12}$. Segundo Crowther (1994: 153), este Demóstenes seria não o trombeteiro, mas o atleta milésio, que teria vencido três diferentes certames em Olímpia, por isso, as três coroas (Moretti 1957: $\left.\mathrm{n}^{\circ} 726,729,732\right)$. Neste caso, a trombeta ressoou para anunciar, de forma vívida, a proeza do atleta em sua tripla vitória olímpica.

A presença do trombeteiro nos jogos foi se consolidando de tal forma desde o século VI, que ao final do século V, no ano de 400 a.C., quando Hípias, um sábio de Élis, redige pela primeira vez a lista de vencedores olímpicos, baseado "nos registros de Olímpia, nas tradições orais e nas lembranças dos que ainda viviam" (Yalouris 1994: 289), ele não inclui somente os participantes das provas atléticas, mas também os nomes dos arautos e trombeteiros que atuavam nos jogos (Bowyer 2016: 189, n. 524).

\section{Competições para trombeteiros}

Seja para dar toques que comunicam momentos importantes ou clamam pelo silêncio, para que a multidão escute o arauto, seja para dar partida em competições ou para regrar o movimento em corridas realizadas em espaços abertos, o tocador de trombeta não precisa ser necessariamente musical, mas forte. As qualidades de um trombeteiro mediam-se mais como as de um atleta do que como as de um músico; qual um lutador, interessava sua força, e não sua musicalidade. Ele se tornou uma figura tão característica dos festivais que

12 «À Démosthène. Les fanfares retentissantes de la trompette tyrrhénienne ont souvant fait résonner de leur âpre écho la plaine de Pise, pour y célébrer une double victoire. Mais si toi, Démosthène, tu as remporté pour tes citoyens de Millet, l'honneur de trois couronnes, jamais pavillon d'airain n'a vibré d'un souffle plus puissant» (M. Rat). Crinágoras de Mileto, poeta da Coroa de Filipe, nascido em torno de 65 a.C., era cliente de Otávia, irmã de Augusto, e de seus filhos. foi criada uma competição para os próprios trombeteiros, assim como havia para os arautos.

Em Olímpia, as provas para trombeta ocorriam no primeiro dia do festival. O vencedor desta prova seria o trombeteiro oficial dos eventos que se seguiam. Inicialmente, esta prova não despertou muito interesse, como sugere o silêncio de boa parte das fontes que se referem aos eventos de Olímpia, e até mesmo das listas de vencedores, que pouco mencionam os trombeteiros que ganhavam estas provas (Paus. V 8, 6-11. P.Oxy. 2082. Crowther 1994: 136-137).

Alguns trombeteiros, porém, notabilizaramse por vencer inúmeras vezes essa competição, como Heródoros - quando ele tocava, ninguém podia permanecer perto dele, de tão forte que tocava (Poll. IV 89). Nos outros três grandes festivais pan-helênicos, Delfos (Jogos Píticos), Corinto (Jogos Ístmicos) e Nemeia (Jogos Nemésios), encontramos registros dessas provas desde o início do século IV a.C. Como a competição para salpinx iniciou em Olímpia em 396 a.C. (96 Olimpíada), é provável que ela já existisse em outras localidades no século $\mathrm{V}$, dado o conservadorismo de Olímpia, que não seria modelo para uma renovação (Crowther 1994: 137-138). A criação desta prova talvez tenha se dado na Beócia, no século V a.C. (Valavanis 1990: 350, n. 119).

Entre 776 a.C., data aceita para a realização da 1a Olimpíada, e 396 a.C., transcorreram 380 anos. Alguns estudiosos se perguntam por que quase quatro séculos se passaram entre o início do festival e a introdução pelos organizadores da prova de trombeta. Enquanto Nigel Crowther (1994: 135) propõe uma explicação genérica ("reflexo da grande democratização do festival quando os Jogos Olímpicos se tornam panhelênicos"), Carolyn Bowyer apresenta uma interpretação mais concreta: no início eram poucas competições e poucos participantes, não se fazendo tão necessária a presença do salpiktes para viabilizar a comunicação do arauto com o público. Mas, na medida em que aumentava o número de competições e de cidades que participavam, maior era o público, a ponto de se transformar em uma multidão barulhenta. Assim, os serviços do trombeteiro se fizeram indispensáveis, "em parte para chamar a 
atenção das pessoas, mas também para sinalizar o começo de um número crescente de provas" (Bowyer 2016: 191). Do mesmo modo, o som alto da salpinx auxiliava na emissão de sinais para os competidores. Ela acrescenta, porém, além deste motivo concreto, que a introdução da prova de trombetas significava também o reconhecimento da "importância crescente dos papéis desempenhados pelo trombeteiro e pelo arauto" (Bowyer 2016: 194).

Há registros de várias competições para salpinx na Antiguidade e conhecemos muitos dos seus vencedores. Apesar do caráter pouco musical, é possível que, aos poucos, a prova tenha se tornado bastante popular. As fontes indicam que o interesse por essa prova aumentou no período tardo-helenístico e no período imperial. Possivelmente, a demonstração de força exercia atração sobre o público, inclusive pelo seu aspecto bizarro. Para a Beócia, contamos com mais de uma dúzia de inscrições referentes a provas de salpinx. Observe-se a cronologia: uma única inscrição remonta ao séc. III a.C.; a maioria data do Império. ${ }^{13}$ Em várias localidades, onde há registros de provas para trombeteiros e arautos, as inscrições mencionam prêmios para o primeiro e o segundo lugar. Era preciso um segundo colocado para escolha do trombeteiro e arauto que anunciaria o vencedor dessas provas (Crowther 1994: 139). Evitava-se assim que o trombeteiro vencedor tivesse que anunciar sua própria vitória - isto soaria como prova de mau gosto, típica dos excessos de Nero, que se aprazia em anunciar a si mesmo perante o público como periodonikes (vencedor de todos os certames da temporada) (Suet. Nero XXIV 1. Dio Cass. LXII 21).

As provas de salpinx tornaram-se tão populares no período imperial que, em alguns casos, passaram a ter valor em si mesmas, não se limitando mais a ser a prova realizada para escolha de trombeteiros e arautos responsáveis por anunciar os vitoriosos. Essa autonomização do certame de trombeteiros ocorreu por exemplo na Tessália e na Tebas egípcia. Nessa última, a prova para trombeta está listada indistintamente como uma das dez modalidades musicais do festival. Como não havia competição para arauto, conclui-se que o trombeteiro, no Egito helenístico-romano, participava da prova pelas suas qualidades musicais, e não pela sua força física.

O nome do vencedor do primeiro certame para salpinx em Olímpia, realizado em 396 a.C., nós o conhecemos através de uma inscrição que informava o vencedor desta prova e da prova para arauto: ele se chamava Timeu de Élis (Moretti 1957: no 374) ${ }^{14}$. A ausência de seu nome em outros testemunhos que reverberassem sua fama sugere que, nos primeiros anos, esta competição não lhes conferia tanto prestígio. $\mathrm{O}$ fato de o vencedor ser local, de Élis, cidade responsável pela organização do festival, pode ser um indicador de que a prova ainda era pouco conhecida, apesar da importância que os organizadores quiseram lhe conferir, ao fazer inclusive o registro do vencedor. Aos poucos, com a popularização da prova, alguns trombeteiros ficaram famosos por suas vitórias.

Outra forma de marcar o reconhecimento público pela vitória, além de uma inscrição, era a dedicação de uma estátua, sem dúvida um prestígio maior. A esse respeito, Plutarco (Praecepta 820b) reporta que vencedores nas provas de trombetas poderiam ser contemplados com esta homenagem, do mesmo modo que atletas, um indicador de que trombeteiros passavam a conquistar fama como vencedores da prova (Bowyer 2016: 198).

Heródoros de Mégara desponta entre os mais aclamados: segundo Nestor (Ath. X 414), venceu dez vezes em Olímpia; segundo Pólux (IV 89), dezessete vezes. Para Crowther (1994: 151), é improvável que tivesse vencido dezessete vezes, pois isso significaria uma carreira profissional de 64 anos, o que nos parece inverossímil. A versão de Ateneu, perfazendo 36 anos, parece mais plausível. Suas vitórias olímpicas devem ser situadas aproximadamente entre 328 e 292 a.C.

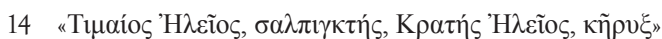
(Moretti, IAG 374). 
No século I d.C., Diógenes de Êfeso venceu cinco vezes em Olímpia, mas, considerando os outros festivais, somou aproximadamente oitenta vitórias como trombeteiro. Por duas vezes unificou os títulos, na qualidade de periodonikes ${ }^{15}$, equivalente a um tenista hoje ser detentor do Grand Slam ou de um pugilista unificar os quatro grandes cinturões ${ }^{16}$. No caso de Heródoros, como não há referências às suas vitórias além daquelas de Olímpia, podemos imaginar que acumulou um número muito superior às dez referidas por Ateneu e Pólux, mesmo que em sua época ainda não houvesse tantas competições como nos tempos de Diógenes de Êfeso. As inscrições gregas não registram nenhum trombeteiro ateniense premiado nos quatro grandes festivais, nem no período clássico, nem no helenístico ou imperial. No entanto, não são poucos os registros relativos aos festivais locais da Ática, inclusive as Teseias, em que haveria uma competição de trombeta.

Há sempre algo de pitoresco na descrição desses trombeteiros, vistos como um híbrido de músico/atleta. Em oposição ao requinte orientalizante típico da figura de citaredos e auletas, sempre suspeitos de efeminação, os trombeteiros eram descritos como glutões, da mesma forma como alguns atletas famosos, como Milo de Crótona, famoso pela sua força, o qual, na segunda metade do século VI, venceu a prova de luta por seis vezes em Olímpia e outras seis em Delfos (sendo a primeira vitória, em cada festival, na categoria infantil). Ateneu (X 415) menciona uma trombeteira comilona que atuou numa parada em Alexandria, e, sobre Heródoros, afirma que consumia enorme quantia de comida e de vinho, o que sugeria semelhança com Héracles. A associação com

15 Vencedor do periodos, que correspondia ao "circuito atlético", composto pelos quatro grandes festivais panhelênicos: os Jogos Olímpicos, Jogos Píticos, Jogos Ístmicos e Jogos Nemésios.

16 O Grand Slam do tênis mundial se compõe das quarto principais competições de uma temporada, por ordem de realização, Australian Open, Roland Garros, Wimbledon e US Open. Os quatro grandes cinturões do boxe moderno são os títulos da WBC, da WBO, da IBF e da WBA. o herói é reforçada pelo suposto hábito de dormir sobre uma pele de leão. Amarantos de Alexandria (Ath. X 414) descreve-o como um tipo baixinho e troncudo. Feitos impossíveis eram-lhe atribuídos, como se fosse portador de uma força hercúlea: soprando duas salpinges ao mesmo tempo, em 303 a.C., teria ajudado o general macedônico Demétrio Poliorcete ${ }^{17}$ em sua conquista de Argos, apavorando os soldados com o volume de seu som (Ath X 415a. Pol. IV 90).

\section{Considerações finais}

Acerca do acompanhamento musical das atividades desportivas, no que se refere ao aulos, a iconografia dos vasos áticos apresenta um volume maior de informações do que a documentação escrita, no tocante não somente à realidade ática. Esta observação poderia ser estendida inclusive para parte do mundo grego colonial e do mundo de influência grega, visto que na Itália, por exemplo, a pintura parietal funerária de Poseidonnia e mesmo a pintura de vasos etruscos trazem representações do acompanhamento aulético do pugilismo (Cerqueira 2016: 194-197, figs.9-11). Ademais, as referências literárias existentes dão conta basicamente do Peloponeso, especificamente de Olímpia, Argos e Esparta.

Esta constatação reforça a convicção metodológica de que se precisa operar no cotejamento entre os diferentes tipos de fonte, neste caso, entre o registro literário e o iconográfico. Uma interpretação que privilegie o documento escrito, como o fez David Larmour (1999), impede que se vislumbre o conjunto de modalidades atléticas que recebiam acompanhamento aulético nos jogos de Atenas ou de outras localidades (modalidades eventualmente sugeridas por meio de atributos). No caso da salpinx, como apontamos, ocorre uma inversão, havendo mais documentação

17 Filho do general de Alexandre o Grande, Antígono Monoftalmo, Demétrio, conhecido como Poliorcete, mais tarde tornou-se o rei Demétrio I da Macedônia (294-288 a.C.), sendo o primeiro dos seis governantes da dinastia dos Antigônidas, que durou até 165 a.C. 
escrita (e predominantemente do período imperial) do que registros iconográficos. Mas as evidências imagéticas da trombeta nos jogos, legadas pelo substrato arqueológico, mesmo que pouco numerosas e por vezes fragmentárias, em contraste com as representações do aulos no contexto atlético, não deixam de ser significativas para nossa interpretação, como é o caso dos fragmentos da cratera ática de Larissa, que informam o uso da salpinx no acompanhamento da hoplitodromia, dado ausente das fontes literárias.

Enquanto instrumento musical, a salpinx apresenta uma dupla utilização: de um lado, um instrumento melódico (mesmo que limitado); de outro, uma espécie de buzina ou alarme, que clama por silêncio e anuncia uma mensagem. Na sua função melódica, é empregada no acompanhamento musical de corrida de quadrigas ou de cavalos, por exemplo. Seus recursos melódicos, no entanto, são bastante mais reduzidos do que de um aulos. Seu valor está muito mais na sua capacidade sonora de anunciar os vencedores, de clamar pelo avanço das tropas, de anunciar que o arauto pretende comunicar uma mensagem à multidão. Melodicamente, seu repertório devia corresponder a fanfarras de chamamento militar, tal como aquela identificada por Annie Bélis (1984: 99-109, figs. 1-3; 1996: 7.) sobre um epinetron conservado no Museu de Eleusis (cat. 10), TOTOTE TOTH, ou como o famoso tara tantara (Enn. Ann. II.143[451]) ${ }^{18}$.
Nessa passagem, segundo Gullög Norquist (2014: 242-243, n. 5), "a mesma sequência rítmica é dada [pelo poeta latino Ênio] como uma fanfarra de trombeta" na tuba ${ }^{19}$.

Como fenômeno cultural, salta aos olhos o aumento do interesse, no período helenísticoromano, pela prova de trombeteiros, que inicialmente tinha um lugar acessório nos festivais. Paralelamente, constrói-se a imagem social do tocador de trombeta como um tipo bizarro, ao qual se atribuem características tão exageradas quanto o altissonante volume que deveria produzir a partir do tubo de sua salpinx. Em princípio, a trombeta, na guerra ou nos jogos, tinha como objetivo produzir um som que pudesse ser ouvido à distância. Dos tocadores de trombeta, esperava-se a potência sonora. Nesse sentido, Pólux (IV 88-90) nos conta sobre um certo Epítades, que fazia ouvirem sua salpinx a cinquenta estádios de distância (quase dez quilômetros!), ou, ainda sobre Heródoros de Mégara, que sopraria com tanta força a ponto de ser insuportável ficar perto dele.

Se, no começo, em um Timeu de Élis, sem apelo popular, os organizadores do festival reconheciam um tocador eficiente para a função comunicativa, com o passar do tempo, o tocador de trombeta se torna uma espécie de pop star, admirado não por qualquer tipo de requinte ou virtuosismo musical, mas por sua força descomunal, que o aproximava do mais popular dos heróis, Héracles.

CERQUEIRA, F.V. The trumpet and the games. R. Museu Arq. Etn., 29:75-91, 2017.

\begin{abstract}
The musical accompaniment of sports is an outstanding feature of games in ancient Greece, either in training or in competitions. This accompaniment was done with wind instruments, namely the aulos and the salpinx (trumpet). Such accompaniment of athletic activities with aulos, mainly in the modalities of the pentathlon, widely represented in the iconography of blackand red-figure Attic vases (6th and 5th century B.C.), has received more attention
\end{abstract}

18 "And the trumpet in terrible tones taratantara blared" (Warmington). At tuba terribili sonitu taratantara dixit (II.fr.143 Warmington = II.fr.18 Steuart). Fragmento identificado como 451 em Nordquist (2014) e Bowyer (2016).
19 Conforme Landels (2002:80), era o correspondente romano da salpinx, adjetivada nos autores latinos como "tirreniana" ou "estrusca", como faziam autores gregos em relação à salpinx. 
from scholars. We aim here to deal with the presence of the trumpet in games, represented with a lower frequency in iconography, but informed by literary sources dating from different periods, mainly from the imperial times (namely Plutarch, Athenaeus and Pollux). We will analyze the following situations: musical accompaniment of races (foot and chariot races), supporting the rhythm of the movements; awards ceremony; advertisements through the emission of signals, with communicative function; and competitions for trumpet players, in relation with the constitution of a social profile of this musician-athlete based on the fame of his well above average strength. This superlative strength, mixed with bizarre customs, makes him a popular type in the Hellenistic-Roman world.

Keywords: Games; Classical Antiquity; Music; Salpinx; Iconography.

\section{Catálogo iconográfico}

Catálogo 1 = Fig. 1

Cratera em cálice (fragmentária), ático, figuras vermelhas. Pintor de Munique 2335. Larissa, Archaeological Museum, inv. 86/101. c. 440-430 a.C.

Referência: Shapiro, 1992: 61, fig. 39A, B. Cerqueira, 2001: cat. no 498 .

\section{Catálogo 2}

Kantharos com uma alça, ático, figuras negras. Grupo de Perizome, III: Grupo de Vaticano G 58. (ABV 345/2). Paris, Biblioteca Nacional, inv. 4960 (354). c. 530 a.C.

Referência: CVA Bibliothèque Nationale 2 (France 10) III H e, pr. 71.1,3,5,10. Jüthner, 1968:27, fig. 2. Cerqueira, 2001: cat. $n^{\circ} 92$.

Catálogo 3 = Fig. 2

Cratera com voluta, ático, figuras negras. Sem atribuição. Atenas, Museu Nacional, Coleção da Acrópole, 654. Pouco posterior à metade do século VI a.C.

Referência: Graef \& Langlotz, 1925: n 654, pr. 41-2. Cerqueira, 2001: cat. $\mathrm{n}^{\circ} 100$.

\section{Catálogo 4 = Fig. 3}

Tampa de uma olpé (tipo de oinochoe), ático, figuras negras. Sem atribuição. Paris, Cabinet des Médailles, 54 (182). Segunda metade do século VI a.C.

Referência: CVA Bibliotèque Nationale 2 (France 10) III J a, pr. 81.6. Cerqueira, 2001: cat. no 497. Foto disponível em: <http://medaillesetantiques.bnf.fr/ ws/catalogue/app/collection/d/3446? vc $=\mathrm{ePkH} 4 \mathrm{LF}$
7w6yelGA1iLESKelDHzOIkKIBmhsMLYzA9TIs HADLqys0>. Acesso em: 15 jul. 2018.

Catálogo 5 = Fig. 4

Kylix, ático, figuras vermelhas. Círculo do Pintor de Nikósthenes (ARV² 133/4). Cambridge, University, 37.17. 520-510 a.C.

Referência: Lissarrague, 1987:72, fig. 57B. Cerqueira, 2001: cat. no 499 .

Catálogo $6=$ Fig. 5

Ânfora panatenaica. Atribuída à Nicomachos (ABV 415/3). Arcontado de Teofrasto. 340-339 a.C. Paris, Louvre, MN 706 (N 3163).

Referências: CVA Louvre 5, III Hg, pr. 5.8-14). Valavanis, 1990, fig. 21. Miller, 2009 :112, fig. 37. Foto disponível em: <https://www.photo.rmn. fr/archive/95-022088-2C6NU0NIFLOQ.html>. Acesso em: 15 jul. 2018.

Catálogo 7

Kylix coberta, ático, figuras negras. Sem atribuição. Boston, Museum of Fine Arts, 95.16.

Em torno de 510.

Referência: CVA Boston 2, pr. 107. Jüthner, 1968: pr. 11. Lissarrague, 1987:55, fig. 33. Cerqueira, 2001: cat. no 494.

Catálogo 8

Cratera em sino, ático, figuras vermelhas. Pintor de Altamura. Grupo do Pintor de Niobides. (ARV 2 593/41; Para 394; Add $^{2}$ 264-5). Ferrara, Museo Nazionale, 2738 (T 311). c. 460-450 a.C. 
Referência: CVA Ferrara 1 (Itália 37) pr. 1-2. Cerqueira, 2001: cat. no 495 .

\section{Catálogo 9}

Cratera em sino, ática, figuras vermelhas. Sem atribuição. Atenas, Museu Nacional, inv. no 12222. Final do século V a.C.

Referência: Kefalídou, 1996: nº $\Gamma$ 100. Cerqueira, 2001: cat. no 496.

Catálogo $10=$ Fig. 6

Kylix, ático, figuras negras. Pintor C (ABV 51/1; Add $^{2}$ 13). Heidelberg, Universität, S 1. c. 575-550 a.C.
Referência: CVA Heidelberg Universität 4

(Deutschland 31) pr. 152.1-3; 153.1.

Neutsch, 1949:40, fig. 46. Kefalídou, 1996: no T 1, pr. 13. Cerqueira, 2001: cat. no 493.

Catálogo 11

Epinetron (fragmentos), ático, figuras negras. Pintor de Safo (ABL pr. 34.1 a-b-c). Elêusis, Museu Arqueológico, inv. no 907. Final do séc. VI

Referência: Bothmer, 1957: 92, 103. Bélis, 1984: $99-$ 109, figs. 1-3; 1996. Cerqueira, 2001: cat. $\mathrm{n}^{\mathrm{o}} 106$.

\section{Referências}

\section{Fontes epigráficas}

$\mathrm{IAG}=$ Moretti, L. 1953. Iscrizioni agonistiche greche . Signorelli, Roma (IAG).

Fontes literárias

Anthologie grecque. Épigrames funéraires et épigrammes descriptives. 1941. (vol. II) Tradução de Maurice Rat, Garnier, Paris.

Anthologie grecque. Épigrammes amoureuses et épigrammes votives. 1938. (vol. I) Tradução de Maurice Rat, Garnier, Paris.

Athenaeus. 1927. The Deipnosophists. Translated by Charles Burton Gulick. Harvard University Press, Cambridge, MA.

Ennius. The Annals of Quintus Ennius. 1925. Edited by Ethel Mary Steuart. University Press, Cambridge.

Pausanias. 1903. Pausaniae Graeciae Descriptio, 3 vols. Edited by Federico Spiro. Teubner, Leipzig.

Philostrate. 1858. Traité sur la Gymnastique. Texte grecque accompagné d'une traduction en regard et des notes par Ch. Daremberg. Libraire de Firmin Didot Frères, Paris.

Remains of old latin I, Ennius and Caecilius. 1935. With an English translation by E. H. Warmington. Harvard University Press, Cambridge, MA.

Seneca. 1962[1920]. Epistulae Morales. II. Books LXVI - XCII. Translated by Richard. M. Gummere. Loeb Classical Library, Londres.

\section{Referências bibliográficas}

Bélis, A. 1996. Fanfarre d’appel aux armes. In: Annie Bélis, (Dir. musical), De la pierre au son. Musiques de l'Antiquité Grecque. (disco). Conjunto Kerylos. Direção musical: Annie Bélis. França, faixa 1, p. 7 (encarte).

Bélis, A. 1986. La phorbeia. Bulletin de Correspondance Hellénique, 110, 1, p.205-218.

Bélis, A. 1984. Un nouveau document musical. Bulletin de Correspondance Hellénique 108, p.99-109.

Bothmer, D. 1957. Amazons in Greek Art. Clarendon Press, Oxford, 1957.

Bowyer, C.S. 2016. Echoes of the salpinx: ancient Greek culture. Tese de doutorado. University of London Press, Londres.

Braun, K.; Haevernick, T.E. 1981. Bemalte Keramik und Glas aus dem Kabirenheiligtum bei Theben. De Gruyter, Berlim.

Crowther, N. 1994. The role of heralds and trumpeters at Greek Athletic Festivals. Nikephoros 7: 135-155.

Graef, B.; Langlotz, E. 1925. Die Antiken Vasen von der Akropolis zu Athen: Die Schwarzfigurigen Vasen. Archäologische Institut des Deutschen Reiches, Druck und Verlag von Walter de Gruyter \& Co., Berlim.

Jüthner, J. 1968. Die athletischen Leibesübungen der Griechen, II: Einzelne Sportarten. Österreichische 
Akademie der Wissenschaften. Philosophischhistorische Klasse, Sitzungsberichte 249, 2.

Kefalídou, E. 1999. Ceremonies of athletic victory in Ancient Greece: an interpretation. Nikephoros 12: 95-119.

Kefalídou, E. 1996. Niketes: eikonographiké melete ton archaion helenikon athletismón. Editora da Universidade Aristóteles, Tessalônica.

Landels, J. 2002. Music in Ancient Greece and Rome. Routledge, London and New York.

Larmour, D.H.J. 1999. Stage and stadium: drama and athletics in Ancient Greece. Nikephoros, Supplement 4, Weidmann, Hildesheim.

Lissarrague, F. 1987. Un flot d'images : une esthétique du banquet grec. Éditions Adam Biro, Paris.

Miller, S.G. 2009. The Berkeley Plato: from neglected relic to ancient treasure, an archaeological detective story. University of California Press, Berkeley.

Moretti, L. 1957. Olympionikai: $i$ vincitori negli antichi agoni olimpici. Accademia nazionale dei lincei, Roma.

Nordquist, G. 2014. The Salpinx in Greek Cult. Scripta Instituti Donneriani Aboensis, 16: 241-256.

Rocha, R. 2010. Um introdução à teoria musical grega. In: PLUTARCO. Obras morais: Sobre o afecto aos filhos; Sobre a música. Tradução, introdução e notas por Carmen Soares e Roosevelt Rocha. Coimbra, Imprensa da Universidade de Coimbra, 2010.

Shapiro, H.A. 1992. Mousikos Agones: Music and Poetry at the Panathenaia. In: J. Neils (ed.). Goddes and polis: the Panathenaic festival in Ancient Athens. Princeton University Press, Princeton.
Sweet, W.E. 1987. sport and recreation in ancient greece: a sourcebook with translations. University Press, Oxford.

Tiverios, M.A. 2008. Perikleische Panathenäen: Ein Krater des Malers von München 2335. Computus Druck Satz \& Verlag, Gutenberg.

Valavanis, P. 1990. La proclamation des vainqueurs aux Panathénées. À propos d’amphores panathénaïques de Praisos. Bulletin de Correspondance Hellénique, 114: 325-259.

Vergara Cerqueira, F. 2018. 'Melodia sangrenta' (Anth. Pal. VI.159): a trombeta e a guerra na Grécia Antiga. Anos 90 25(47): 149-188.

Vergara Cerqueira, F. 2016. To march in phalanx, to jump with weights, to knead the bread, to tread the grapes. What is the aulos for? Archimède. Archéologie et Histoire Ancienne 3: 187-205.

Vergara Cerqueira, F. 2005. Esporte e música na Grécia Antiga: uma abordagem baseada na interface entre a iconografia dos vasos áticos e os textos antigos. Classica 17: 165-183.

Vergara Cerqueira, F. 2001. Os instrumentos musicais na vida diária da Atenas tardo-arcaica e clássica (540-400 a.C.): o testemunho dos vasos áticos e de textos antigos. 3 vols. Tese de doutoramento. Universidade de São Paulo, São Paulo, 2001.

West, M. 1992. Ancient Greek music. University Press, Oxford.

Yalouris, N. 1994. The Olympic Games in Ancient Greece. Ekdotike Athenon, Atenas.

Zimmer, K.B. 2015. Der Tübinger Waffenläufer: ein griechisches Meisterwerk aus der Zeit der Perserkriege. Kleine Monographien, Band 2. Universität, Tübingen. 